\title{
Toward a Sociological Theory of Labour Relations
}

\author{
CARL GARRY*
}

\begin{abstract}
During the 1970's unionization among professional employees in Canada has increased and this trend has been evident among university faculty members. The case study of unionization of faculty at "Eastview University" shows that the literature of voluntary associations and consideration of the historical, political and economic environment of unionization is relevant to the study of unionization in Canada. The literature of labour relations has emphasized economic considerations and been dominated by practitioners.

The case study shows that the university's faculty association was an expressive type of voluntary association. Changes in the university's environment led to increased pressures on faculty members and they experienced a sense of powerlessness. The faculty association became a faculty union, an instrumental association. Both faculty association and faculty union performed functions common to voluntary associations, conferring status and integrating the group. Economic factors were not the major factors for unionization at Eastview and the socio-psychological factors of insecurity and lack of full status as professionals were more influential. Further consideration of socio-psychological factors, following the model given in the article, will lead to fuller understanding of unionization and the role of professionals in bureaucracies.
\end{abstract}

\section{RÉSUMÉ}

Tel qu'indiqué dans le tableau $n^{\circ} 1$ qui suit, au cours de la période entre 1965 et 1975, le nombre de demandes reçues par la Ontario Labour Relations Board et venant des corps de métier dont les membres cherchent à se syndiquer a dramatiquement augmenté. Tandis que la totalité de syndicats immatriculés restait assez stable, le nombre de corps de métier syndiqués grimpa de 2 en 1965 à 52 en 1975. L'augmentation est même plus importante quand nous nous rendons compte qu'en 1965 les demandes acceptées de ces groupes ne représentaient que 83 sur 20,500 employés ou .01\% de ceux couverts par les demandes.

* Professor of Administrative Studies and Associate Dean, Atkinson College, York University 
Par contre, en 1975-76, les 52 demandes acceptées pour immatriculation venant des corps de métier ont couvert 6,949 (approximativement 21\%) sur la totalité de 26,100 employés qui cherchaient à se syndiquer au cours de l'année en question. Tout indique que la tendance à se sundiquer continuera, en particulier parmi les corps de métier qui travaillent dans le cadre d'une grande bureaucratie telle que l'université ou une agence de services sociaux et communautaires.

L'exposition du cas qui suit tente de nous éclairer les démarches entreprises par les enseignants universitaires pour se syndiquer - un phénomène social plutôt récent mais croissant. Avant 1970, les enseignants des universités anglophones partout au Canada ne s'étaient pas syndiqués.

En se syndiquant, les enseignants universitaires ont ménagé une occasion aux chercheurs, spécialistes dans la sociologie des organisations et des professions libérales, de mieux approfondir leur compréhension de la nature changeante des corps de métier qui oeuvrent dans le cadre de grandes organisations complexes et conventionnelles. Les sociologues s'intéresseront aux rapports changeants des corps de métier tels que ceux entre les professeurs universitaires et les institutions ou les bureaucraties au sein desquelles ils s'acquittent de leurs fonctions.

L'élaboration d'une compréhension sociologique satisfaisante ne peut progresser d'une façon appréciable avant que les sociologues accumulent tout un éventail de documentation basée sur des expositions des cas existants. Cette étude s'avère une première contribution à cette documentation requise. 


\section{FIGURE 1}

OLRB Certifications of Professional Employees April 1, 1955 to March 31, 1976

\begin{tabular}{|c|c|c|c|c|c|}
\hline & \multirow{2}{*}{ Fiscal Year } & \multicolumn{2}{|c|}{$\begin{array}{l}\text { Total Cases } \\
\text { Certified }\end{array}$} & \multicolumn{2}{|c|}{$\begin{array}{c}\text { Professional Cases } \\
\text { Certified }\end{array}$} \\
\hline & & Number & Employees & Number & Employees \\
\hline $1965-66$ & $\ldots \ldots$ & 737 & 20,500 & 2 & 83 \\
\hline $1966-67$ & $\ldots \ldots \ldots \ldots \ldots \ldots \ldots \ldots \ldots \ldots \ldots \ldots$ & 709 & 25,800 & 6 & 302 \\
\hline $1967-68$ & & 643 & 25,800 & 2.4 & 2,246 \\
\hline $1968-69$ & & 696 & 23,900 & 11 & 1,653 \\
\hline $1969-70$ & $\ldots \ldots$ & 672 & 21,800 & 11 & 1,219 \\
\hline $1970-71$ & & 701 & 21,700 & 12 & 1,806 \\
\hline $1971-72$ & & 550 & 17,300 & 7 & 94.1 \\
\hline $1972-73$ & & 753 & 22,800 & 8 & 706 \\
\hline $1973-74$ & & 867 & 26,600 & 26 & 5,100 \\
\hline $1974-75$ & & 894 & 27,300 & 32 & 2,655 \\
\hline $1975-76$ & & 765 & 26,100 & 52 & 6,949 \\
\hline
\end{tabular}

* Includes units of nurses, social workers, engineers, university teachers, librarians, and psychologists.

\section{LIMITATIONS OF THE INDUSTRIAL RELATIONS LITERATURE}

Because faculty unions are a relatively new phenomenon there has been little opportunity for such a body of sociological literature to be developed. The fact remains, however, that sociologists in Canada have, with few exceptions, demonstrated remarkably little interest in the study of unions, with the result that the field, which is more commonly known as Industrial Relations has been preempted by labour economists, labour lawyers and some political scientists and historians. Dunlop (1972:548) notes:

In the United States and Great Britain the study of industrial relations is, in large part, an offshoot of economics, although other fields have made some contributions. In France it appears as if the industrial sociologists have been most concerned with developing the field. In many countries it is largely the preserve of lawyers. 
The dominance of the field by those who are primarily oriented to the practice of labour relations, either as advocates or consultants has, in the opinion of the researcher, resulted in the development of a pragmatically useful but theoretically limited analysis. Marshall and Perlman (1972:545) confirm this aspect of labour relations literature in their discussion of collective bargaining theories:
Much of the literature on industrial relations - or the interactions between unions, management and specialized government agencies dealing with union management relations - is factual and descriptive. Essentially, this field has been the preoccupation of practitioners and scholars concerned with the practical issues involved in collective bargaining or dispute settlement. There have therefore been very few attempts to formulate general theories of industrial relations.

It is not surprising, therefore, that much of the literature pertaining to unionization is concerned with the "how to" rather than the "why" and causal analysis gives way to description of legal precedent and "common practice" in grievance procedure and arbitration or to weighted arguments - pro and anti union - leading to particular legal decisions and arbitration awards.

Because labour lawyers and labour economists are employed to represent either the management or the union's side of a dispute they become identified, over a period of time, as either management spokesmen or union spokesmen. Industrial relations practitioners invariably become reliant on either management or labour for their livelihood and in order to attract new clients must indicate where their sympathies lie and must argue forcefully and successfully for their clients. The necessity to build up trust and loyalty among their clientele places practitioners in a strong dependency position vis-à-vis their employers which creates a threat to the objectivity of the labour relations literature.

A further limitation of the literature being generated by labour relations practitioners emanates directly out of the context in which their arguments are made. Labour relations board tribunals in Canada have quasi-judicial powers to make decisions which are legally binding on both parties. Hearings take on many of the aspects of the courtroom and evidence is presented by each side in support of its position. Practitioners, who know the rules of the game, know that certain types of evidence are given precedence over other types. A well known Toronto labour lawyer stated:

You have to back your arguments up with lots of tangible evidence. I always have lots of statistics - you know - comparative figures from other industries and things of that sort. If you can find one or two good clear cut precedents which involved a similar type of dispute - and where a decision was made that you feel your client could live with - you've got it made. I try to go in with four or five good points and stick with them. If you try to drag in all kinds of extraneous information they will get annoyed with you for wasting their time and rule against you. They're not interested in the social niceties of the case. You've got to stick to the facts of the matter.

D.D. Carter, a professor from the Faculty of Law, Queen's University, underlined the limitations of the existing approaches to labour relations when he told a group of his fellow labour relations practitioners (Gunderson, 1975:63) at a symposium: 
Perhaps we shouldn't pay such adherence to the collective bargaining model. Perhaps we should look for other solutions. I know this is probably heresy within this group because we all have a vested interest in collective bargaining.

While acknowledging the significant contribution made by labour economists in furthering our understanding of labour relations it is important to note a seriously limiting and constraining aspect of their approach which unfortunately runs through the literature. Writers such as the Webbs and Commons represent a major body of economic thought which has been described by Bauder (Marshall and Perlman: 1972:21) as one which sees trade unionism as essentially an economic movement to improve wages. Dunlop (1972:6), who is the acknowledged dean of labour economists, summarizes the problem succinctly:

Most writings on theories of the labor movement. . show a tendency to seek a single and usually over-simplified statement of labor organization. But the labor movement is highly complex and many-sided. The "history" does not readily lend itself to any single formula.

The researcher is in complete agreement with Dunlop on this point and would argue that there is no single or simple cause for the growing unionization of professional groups such as university faculty members. The rise is undoubtedly closely related to what labour economists now characterize as "stagflation" where salaries have not kept pace with the rising cost of living. But the causes of the unrest among professionals which have led to unionization are dynamic and complex. Waisglass (Gunderson, 1975:25) in a discussion of public employee unrest in Canada states:

What complicates the current employee struggles to restore, maintain, or improve relative income positions is the related but distinctly different question of status. ... strikes are much more than an effort to improve relative income.

In the opinion of the researcher, sociologists need to know more about the role played by socio-psychological factors such as status in preparing professionals working in the public sector for collective bargaining. Evidence from the researcher's case study of Eastview University* suggests the formation of a faculty union is not solely or primarily for higher salaries.

In order to fully account for the emergence of faculty unions we need to know all the conditions and factors - not only the economic ones - which have contributed. The case study of faculty unionization at Eastview University is an attempt to broaden the present analytical base of Canadian industrial relations literature by introducing a sociological perspective utilizing the literature on voluntary and formal organizations. In presenting this case study material the researcher identifies a number of interrelated factors which should facilitate the development of a theoretical system which would provide for a more integrated understanding of the unionization of professional groups.

\section{The Case of Eastview}

Eastview University was established in one of Canada's old and conservative cities in the mid-1800's. It was intended to provide a Catholic education, at the college level, for young men. In its early years, Eastview served as an indoctrination and recruitment centre.

*A pseudonym is used to respect the confidentiality of persons and institutions. 
for the Catholic clergy, a pattern which was interrupted by World War II. Following the Second World War, Eastview experienced an increased enrolment which included many veterans who received financial assistance from the Canadian government to enable them to complete their college education. However, few of the veteran students who completed their education at Eastview entered the priesthood. World War II was a watershed in the history of the University because it marked the beginning of a sharp decline in the number of young men who were willing to enter the religious life. The clerical faculty was forced to acknowledge that few young men were joining their ranks and that enrolments were declining. They began to recruit lay faculty.

In 1968 Eastview, in anticipation of secularization, elected to become a co-educational institution. The appointment of the University's first lay president in 1970 marked the end of a period of benevolent authoritarianism and the beginning of a rational-legal authority system (Weber, 1956) at Eastview. The University acquired a new provincial charter and the existing facilities which were owned by the Roman Catholic Church were transferred to the new corporate structure under an unusual agreement which gave back a large mortgage to the archdiocese as payment for the latter's agreement to transfer all buildings, books, furnishings and other assets to the university's new corporate structure. Since the provincial government refused to provide capital compensation, principal and interest payments on the 5-year mortgage had to be derived from student tuition fees and government grants, along with regular ongoing operating costs of the University.

The imposition of these additional costs during a period of particularly high inflation created a set of unusually difficult economic circumstances for the university during the period 1970-1975. It was against this rapidly shifting background of socio-economic events that the University's faculty association, a purely voluntary organization, underwent some extremely radical changes until it ultimately transformed itself into a full-fledged faculty union (cf. Johnson, 1975:51-59; Rose, 1966:58).

\section{Consideration of the Economic Variables}

It should be noted, however, that of the fourteen universities in the four Atlantic provinces - all of which were experiencing similar inflationary pressures - Eastview University was, at the time of writing, the only university in the region where faculty have unionized. There is no evidence to suggest that the unique set of economic circumstances at Eastview had adversely affected faculty salaries. Faculty salaries at Eastview for the four year period $1970 / 71-1973 / 74$, immediately prior to unionization, were at least comparable, and in many cases superior, to those of other universities in the region. Indeed the arguments made by the labour economists which have been cited above are greatly undermined when one considers that starting salaries at Eastview compared favourably with the starting salaries at universities located in regions of the country which are more prosperous economically.*

\footnotetext{
* In 1973/74 the difference between starting salaries at Eastview and those of the University of Toronto and York University, for example, did not exceed $\$ 700.00$ per annum for any rank and indeed Eastview's salaries exceeded those at the University of Toronto for all ranks above that of lecturer. At the rank of associate professor there was a salary difference of less than $\$ 130.00$. Other Ontario universities with which Eastview's salaries compared favourably in 1972 (given the economic disparities between the regions) included McMaster and the University of Western Ontario.
} 
Data from questionnaires distributed at Eastview indicated that faculty members at Eastview were almost equally divided in their perceptions regarding their salaries. The following responses were given to the question:

For the work you are required to perform, which of the following best reflects your opinion concerning salary remuneration from Eastview?

$\begin{array}{lccc} & \text { Number } & & \begin{array}{c}\text { Per cent } \\ \text { of total }\end{array} \\ \text { Exceptional } & 0 & & 0 \\ \text { More than adequate } & 2 & & 3.8 \\ \text { Adequate } & 23 & & 43.4 \\ \text { Less than adequate } & 21 & & 39.6 \\ \text { Very much less than adequate } & 7 & & 13.2\end{array}$

53 of the 54 respondents answered this question. 25 of the 53 considered their salaries less than adequate. Only seven or $13.2 \%$ of the respondents indicated strong dissatisfaction with their salaries which, in the opinion of the researcher, is not a sufficient condition for unionization.

Faculty respondents provided further evidence that money was not a primary contributing factor to unionization at Eastview. The following responses were given as first choice to the question:

In your opinion, which of the following responses best describes the reasons why the faculty members at Eastview sought unionization? (If more than one response, number in order of importance.)

Prior to unionization there was a climate of insecurity at [Eastview].

$27 \quad 50.9$

Faculty members were not treated as professionals and in most educational matters their expertise was ignored by the administration.

Faculty salaries were unrealistically low compared to other occupational groups.

Community indifference to faculty needs necessitated a "banding-together" of faculty members to draw attention to their grievances.

Unionization is necessary to bring about radical social changes in our society.

The two highest responses related to factors familiar to sociologists studying organizations: the organizational environment and the status of professional groups within a formal organization. The responses "climate of insecurity" and "not treated as a professional" counted for 77.3 per cent of all the first choices given by the 53 faculty members responding. As a first choice response, money came third. However, $50 \%$ of the respondents who indicated a second response chose it as their major second choice. Responses to this question clearly indicate that economic factors were not the major factors contributing to unionization at Eastview. 


\section{Toward a Sociological Explanation}

If, as the data indicates, salaries were not the primary condition which contributed to the formation of the faculty union at Eastview, then we are faced with the question of "What other condition or set of conditions were responsible?" The researcher would argue that the literature on the sociology of voluntary and formal organizations can be usefully employed in identifying other relevant factors.

Of the 175 faculty members at Eastview, approximately 125 were members of the faculty association. Prior to 1970 , the faculty association was a relatively docile organization sponsoring a limited number of faculty social occasions each year (cf. Gordon and Babchuk, 1966). A major characteristic of the association was its deference to university and governmental authority. The faculty association's deference was seen to be in keeping with the "proper" demeanour for university professors.

Eastview's faculty association served several very important functions. The association provided its members with a potential vehicle for upward social mobility. It provided status within the university for the president and other members of the association's executive (cf. Gordon and Babchuk, 1966:24). The president of the university frequently invited the president of the faculty association to join him and a group of visiting dignitaries for dinner in the president's private dining room.

The executive of the faculty association provided another avenue for upward social mobility insofar as the executive formed a ready pool of talent from which the university administration could and did draw whenever a new administrative appointment was being considered. In this way the faculty association provided for its members, particularly those who were pursuing organizational careers and concerned with administration rather than professional careers, concerned with scholarship, an opportunity structure which enabled them to experiment with, "try on" and familiarize themselves with an administrative role which they might be called upon to play at some later stage in their careers. For those older or less scholarly inclined faculty members who had decided to pursue an administrative career, the faculty association served as an ideal anticipatory socialization agent. Many Eastview faculty members indicated to the researcher that they perceived a move into administration as a promotion. As a former president of the faculty association put it:

It sure took a lot of time but I'm glad I did it. I learned a lot and of course it makes people notice you. When the administration wants to promote someone upstairs they are sure to think of you. You've had those opportunities to hob nob with the brass. I have no doubt that being president of [the faculty association] made me more acceptable for chairmanship of the department and now there's something a lot bigger that they've mentioned to me. If they do decide to have one more VP I know they're thinking of me as a possibility.

The faculty association executive also served an important mediating function within the university. Members of the executive, who were usually full professors, were frequently called upon by both administrators and faculty to use their "good offices" to mediate disputes (cf. Gusfield, 1966:231). In this respect, the association performed an important communications function providing an acceptable channel of communications between faculty and administration when normal channels became clogged resulting in message distortion (cf. Katz and Kahn, 1966).

For its part, the faculty association executive attempted to communicate faculty needs 
to the administration but this information was imparted without any real expectation that the information would be acted upon. Faculty association members were neither willing nor able to employ any real pressure on the university's administration to persuade them to agree to faculty demands. Instead there was evidence to suggest that the administration viewed the association as an important control mechanism for cooling out dissident faculty members and keeping them in line. As one member of the association's executive stated:

I spend a lot of time meeting informally with [the Dean of Arts] . I am always being invited for lunch or a drink and almost every time he casually mentions something he wants me to do. It's never anything hard, just talking to someone who has a gripe, solving it for him if I can and then letting [him] know if there's still going to be some problem.

Members of the faculty association's executive were normally able to perform this control function by appealing to the conservative and widely shared values of the profession.

Another way in which the association served as a control mechanism was by diverting faculty attention from potentially explosive internal political controversial issues and focusing on more scholarly concerns. The association avoided conflict, shied away from controversy and emphasized "professionalism." The association accomplished this by various means which included sponsoring a number of professional development seminars each year, inviting several well known respected scholars to speak on what were, in terms of university policies, essentially non-controversial topics. The administration supported and helped fund the professional development seminars because of the benefits derived from them which included a certain amount of status and prestige conferred on the university by the prominent visiting speakers. These activities helped to shift attention away from controversial topics and were able, for a time, to stave off any serious ruptures or confrontations between the faculty and the administration.

Another important function which the faculty association performed was helping integrate new faculty members into the university. The association helped to provide new faculty with a sense of belonging by giving them an opportunity to volunteer their services on one or more of the various committees which were responsible for organizing the association's various social and cultural activities. In this way the new faculty were given an opportunity to meet and work with colleagues outside their own department. These social contacts within the university were extremely important to newcomers and their spouses. A common complaint was:

It is extremely difficult to meet people in [this city] and make new friends. [They] are very polite but they don't invite you into their homes. I've been here three years and I still feel and am treated very much like a visitor or transient who is just passing through. I'm still very much an outsider. I get tired of just being with university people all the time but outside the university it is impossible to make friends. After three years I am still very much a stranger and totally dependent on the university for friends.

Established families in the city, for their part, had a clear cut stratification system (Christiansen-Ruffman, 1974:26-28) and were not friendly to outsiders. The faculty association by sponsoring a number of social and cultural activities, provided an important forum for faculty social interaction.

Despite the various functions performed by the faculty association, the organization 
nevertheless underwent a radical transformation in 1974 when it was officially reorganized as a faculty union. The certification of the union as the official and legally recognized collective bargaining unit for the faculty dramatically altered traditional relationships between the faculty and administration at Eastview.

An important aspect in the emergence of the union was the organization's rapidly shifting political, social and economic environment (Perrow, 1970). The faculty association's economic and political environment in the years $1970-1975$ were marked by a high degree of intra-organizational competition, particularly among institutes of higher learning, for very limited Maritime government resources. For example, Halifax, with a population of 130,000 people, contained four government sponsored universities: Dalhousie, Kings, Mt. St. Vincent and St. Mary's. Also located in Halifax were three other degree granting institutions: Nova Scotia Technical College, Nova Scotia College of Art and Design and the Atlantic School of Theology. Other provincial institutions which also were vying for government funds included Acadia University at Wolfville, St. Francis Xavier at Antigonish and the Agricultural College at Truro. With a population of only 750,000 people and a low level of industrialization, Nova Scotia's tax base was severely taxed by the increasing financial demands being made by post secondary education.

In an effort to rationalize the whole structure of education, the Premiers of the three Maritime provinces established the Maritime Commission of Higher Education in 1973. The commission was based in Fredericton and Sr. Catherine Wallace, a former president of Mt. St. Vincent, was appointed to head the commission. Replacing the old University Grants Committee, the new commission was designed to assist the government in the creation of a more centralized university system. A former member of the Nova Scotia University Grants Committee told the researcher that the Maritime Commission of Higher Education marked the end of an era of autonomous universities and program duplication and the beginning of increased university accountability and program specialization.

The system of grants to universities in the province in which Eastview is located paralleled those of other Canadian provinces. Eastview received a grant of approximately $\$ 2,000.00$ for each full-time student enroled. The grant system led to the creation of an enrolment economy. By tying grants to the number of student enrolments, the government encouraged unplanned growth and a fierce intra- and inter-university competition for students. Courses were not seen to be intrinsically good but were good mainly if they could attract students, with the result that the less popular courses were not offered. With the increase in student enrolments, capital costs for academic buildings, libraries, student housing and recreational facilities sky-rocketed. The demands of post secondary education became so enormous that government had no alternative but to intervene, albeit reluctantly. However, an added spur to government action was the growing disenchantment in the society with the educational system.

Needless to say the provincial government's increased involvement between 1970-1973 contributed to the faculty association's transformation into a faculty union. With the departure of the clergy and the secularization of the university in 1970, faculty members at Eastview had expected an increase in their own status and power in the university. But the increased government involvement and growing social disenchantment with universities prevented faculty expectations from being realized. Faculty frustrations 
began to mount once it became apparent that whatever faculty rights existed were being eroded (cf. Rose, 1966:57). Faculty quickly began to realize that some collective action was required to stave off further status reversal. These sentiments were voiced by a member of the Eastview faculty association's executive when he told the researcher: "If we don't get organized and protect our interests pretty soon then there'll be nothing left. The administration will walk all over us!"

According to the vice-chairman of Eastview's board of governors, the absence of democratic practices and procedures and the debt were part of the clergy's legacy to the newly secularized university. Faculty members who had unrealistic hopes for the immediate and total democratization of Eastview became disenchanted and further frustrated when the new administration filled the power vacuum created by the clergy's withdrawal and indicated that it was not immediately about to share its new found power. The faculty began to realize that the prospects for an early democratization of the university were not very bright.

In an attempt to shore up their weakening position, the faculty association took the initiative and requested that the university bargain collectively with faculty giving the faculty association voluntary recognition as the faculty's unofficial bargaining agent. The association presented a proposal for voluntary recognition to the university administration and the Board of Governors on several occasions in 1970 but the administration refused to bargain collectively with the faculty. The proposal appears to have threatened the new administration which responded by taking a hard line which led to a major crisis of confidence within the university and brought the faculty association into direct confrontation with the administration.

The first president of the faculty union described this confrontation as follows. The crisis was triggered when the newly appointed president established his leadership style by firing fourteen faculty members, some of whom were tenured. The faculty association was informed that further cuts in faculty could be expected. The normally docile association turned militant, angrily protesting the firings and denouncing the administration's actions as irresponsible. The administration responded by placing large display advertisements in local and national newspapers advertising for new faculty to fill the vacancies created by the firings. Another display advertisement indicated that Eastview had a number of openings across the university and invited interested faculty to apply. When the faculty association attempted to intervene on behalf of the faculty who had been fired and to seek clarification regarding the administration's new recruitment campaign, they were infantilized. The administration adamantly refused to discuss anything with the association's representatives maintaining that it was the administration and not the faculty association that was charged with the responsibility for running the university. Instead of a discussion, the association's representatives received veiled threats of a further administrative tightening up in the form of increased class size and longer teaching hours.

It was as a result of the sociological factors described above that the faculty association was transformed from a docile, passive, expressive type of association into an active, militant, instrumental type of organization - a union (cf. Gordon and Babchuk; 1966:25; Moore, 1960:387-97).

As a result of its poor administrative practices and its inability to establish satisfactory 
working relationships with faculty, the administration succeeded in making itself a visible target to which responsibility could be affixed for all the grievances and frustrations that had been generated in the system. The crisis of confidence had, in the view of many faculty members, unmasked the administration as "the enemy of the faculty" and the faculty felt morally obliged to fight. The warriors were a group of young activists who developed a high profile at the time of the crisis by advocating that a "tougher line" with the administration was necessary if faculty hoped to preserve its professional prerogatives (cf. Gusfield, 1966). At the numerous meetings held following the crisis, the activists argued persuasively that since the administration refused to recognize or even talk to the faculty association on any of the important issues, unionization was the only answer. The unionists repeatedly pointed, quite correctly, to the fact that once association turned itself into a union the administration would be obliged to negotiate with the faculty.

Refusal to negotiate would subject them to penalties provided under the province's labour relations act.

The question of whether or not to unionize was quickly transcended when the Canadian Union of Public Employees (CUPE) made its bid to become the official bargaining agent for the faculty. Some members of faculty, disillusioned with the faculty association's inability to intervene, actively campaigned to persuade their colleagues to sign CUPE membership cards. The association, in an attempt to prevent a CUPE takeover, sought and received help from the Canadian Association of University Teachers (CAUT) in the person of a skilled union organizer from Quebec. The organizer worked closely with a newly elected executive and convinced them of the necessity to form their own union, retaining a strong CAUT affiliation. The issue of whether or not to have a union was quickly submerged in an emotionally-charged struggle between faculty who supported CUPE as the official bargaining agent and those who supported CAUT. Approximately $80 \%$ of the faculty of Eastview were evenly divided in their support of these two groups. However, the remaining $20 \%$, a group of strong-minded conservatives who supported neither CAUT nor CUPE, felt compelled to lend their support, albeit reluctantly, to CAUT. This gave CAUT the majority necessary to present itself to the Labour Relations Board as the official bargaining agent. The Labour Relations Board granted the faculty association certification as a union thereby completing the transformation from faculty association to faculty union.

The period immediately prior to certification had been a time of intense indoctrination for faculty (cf. Johnson, 1975:60). CUPE organizers created an atmosphere which was highly-charged emotionally. Ideological and rhetorical statements were commonplace and issues were presented in simplistic terms with "us," the faculty, against "them," the administration. The researcher observed a growing militancy among faculty members which served to persuade faculty that sympathy with a collective bargaining unit was proof of professional, not administrative, loyalty.

The pre-certification period was a time of intense anticipatory socialization. The period was accompanied by a dramatic increase in both formal and informal meetings. Union organizers from both CUPE and CAUT introduced faculty members to a new vocabulary in which phrases like "Labour Relations Board," "residual rights," "arbitration," "bargaining unit," "community of interest" and even such words as "muscle" and "clout" were constantly repeated. A number of faculty members commented on 
the marked increase in the number of in-office and at-home telephone conversations between faculty concerning the issues surrounding unionization (cf. Rose, 1966:57). A typical faculty member recalled receiving eight telephone calls and two visits from other faculty members during one Friday evening and Saturday morning period. While some of the phone calls requested information, most were expressions of group solidarity. By the time the Labour Relations Board granted the faculty association certification as a union, the transformation of faculty association to union had taken place in all but name.

The emergence of the faculty union was at once both integrative and divisive. By cutting across various disciplines, seemingly heterogeneous groups were brought together to fight for the union's cause. However, some senior faculty members who had actively participated in the faculty association became only nominal members of the faculty union (cf. Gusfield, 1966). The union, for its part, tried to minimize its differences with CUPE supporters by co-opting some members onto its committees. The truce, nevertheless, has been an uneasy one.

Another divisive aspect involved the professional librarians who sought to broaden accessibility to the faculty association by being included in the faculty bargaining unit. The vice chairman of the province's labour relations board told the researcher that the faculty representatives at the labour relations board hearings did not present a very strong case for including professional librarians in the bargaining unit (cf. Gordon, 1966:24). As a result, the Labour Relations Board ruled that the professional librarians at Eastview did not share a community of interest with faculty and on these grounds excluded them from the bargaining unit. The decision, in effect, denied the university librarians faculty status. Many of the professional librarians believed that the faculty union did not wish to give faculty status to the librarians and deliberately presented a weak case on their behalf at the Labour Relations Board hearing. The librarians felt that the faculty had sacrificed their interests and they resented it. The professional librarians continued to try to negotiate certain faculty prerogatives, but a year after the faculty union was formed, they realized they had lost the battle. The chief librarian resigned and supporters appealed to the national library association who, in an unprecedented move, voted to censure Eastview for refusing to accord the librarians the usual professional prerogatives. Clearly, denial of membership in the faculty union meant both loss of status and loss of tangible benefits for the librarians.

Several dysfunctional aspects accompanied the birth of the faculty union. The department of business and commerce, generally acknowledged as one of the leading departments in Canada, received resignations from one-half of its faculty members who protested the formation of a faculty union. Members of the business faculty, by virtue of their training, identified strongly with management. Many carried on extensive research and consulting practices in commerce and industry and felt compelled to resign rather than be "scooped up" into a union. As one of the faculty who left the University told the researcher:

I'm an administrator myself and I went to [Eastview] to teach students to be managers. I liked teaching but the only way I could equal the salary I'd get in business was by consulting and I don't see how you can teach students about business administration if you're not involved yourself. It's not that I don't like teaching, but there's no way I'm going to be part of any union. 
The resignations decimated what had been, until unionization, a first-rate business faculty.

Unionization also forced a number of highly motivated and exceptionally competent faculty members in the faculty of arts, who were accustomed to negotiating their own contracts, to bargain collectively. As a result several of them left Eastview thereby depriving the University of some of its top talent. With a union in the house, replacements for these positions with similar credentials were difficult to recruit, according to one departmental chairman.

The creation of the faculty union had a significant effect on the recruitment and selection of all new faculty. Eastview developed a new organizational character (cf. Clark, 1966; Selznick, 1966) which began to attract potential faculty who were prounion and to repel others. Some potential new faculty expressed hesitancy and concern about the prospect of joining a unionized faculty while others were openly enthusiastic about it.

Undoubtedly, one of the most dysfunctional aspects of unionization at Eastview was that the time and energy required to launch the faculty union was time and energy which was diverted from scholarly activities. The union's business and its related activities permeated life at Eastview for almost a year, making it impossible for faculty members to escape in order to concentrate on course preparation and research.

Finally, agreements between the administration and the union necessitated that everything including tacit understandings which were implicitly understood under the association be made explicit. Whether the union will provide greater faculty flexibility or less than its predecessor the faculty association remains to be seen. Perhaps even more important for the sociologist is whether or not the new changes will hold or whether, within a few years, the process will reverse itself with the union applying to decertify and revert to a faculty association.

\section{SUMMARY}

The case study of Eastview University's faculty association has permitted a close sociological examination of a voluntary association which experienced considerable social, political and economic pressure, necessitating a major change in the organization's raison d'etre.

The association was initially an expressive type of organization. With increased pressures on university faculty, imposed by the government and by the University's administration, the association's members experienced a sense of powerlessness and insecurity.

The association provided its members with an important mechanism for bringing about much needed change and integrating changes into the system by establishing, through unionization, a set of predictable practices and procedures. Thus the process of unionization shifted the concern of the association and transformed it into an instrumental type of organization designed to provide access to the university's administration. The union was the faculty's mechanism for instituting social change and acquiring power.

The faculty association and the union performed a number of common functions. Both associations provided a creative opportunity for members to learn "how things 
are done." In addition, because both the faculty association and the union were associations with low accessibility, they performed status defining and status conferring functions. By excluding librarians, the union effectively denied this group faculty status. Both the association and the union performed integrative functions by providing an opportunity for their members to work together for a cause, thereby providing them with a sense of belonging and personal satisfaction. The faculty union cut across the various disciplines and brought heterogeneous groups together.

Conflicts existed between different groups negotiating for power within both association. The faculty union was controlled by younger assistant professors. With the emergence of the union, some members experienced status reversal in the association and became nominal members and less committed than they had been to the faculty association.

It is clear from the case study of Eastview University that the association and the union performed many similar functions which have been shown in the literature to have been performed by various other types of voluntary associations. The study is important in that it allows for a clearer understanding of the change process in voluntary associations and the importance of the historical, geographical, political and economic environment in this process. In future investigations of voluntary associations, sociologists might be advised to give these factors added consideration.

In conclusion, the case study of the faculty union at Eastview has permitted a close sociological examination of the emergence of one of the first faculty unions in Canada. The study has enabled the researcher to identify a number of serious limitations to the development of a satisfactory body of labour relations literature. The dominance of the field by labour relations practitioners has created a bias in the literature which, in the opinion of the researcher, has contributed to the failure of social scientists to develop a satisfactory theory of labour relations.

The case study of unionization at Eastview provided an important opportunity to test traditional economic theories which maintain that salaries are the major contributing factor to unionization. While traditional economic theories may have provided suitable explanations for the rise of blue collar unions in the past, these theories were not able to provide a satisfactory or compelling explanation for faculty unionization at Eastview. Faculty salaries were found to compare favourable with salaries at other universities within the Atlantic region as well as in Ontario. The questionnaire responses given by faculty members from Eastview further undermine the labour economists' thesis. Respondents who were asked to rank factors which had contributed to unionization by order of their importance ranked salary considerations third, behind more important sociological factors like status and "not being treated as professionals." The study has demonstrated that while economic factors contributed, they were not the prime factors behind the unionization of faculty at Eastview. Instead, such factors as organizational environment, lack of status and a sense of powerlessness were found to be the prime motivating factors for unionization.

The sociological literature of voluntary and formal organizations provided a valuable framework for the discussion of unionization at Eastview and facilitated identification of the important sociological variables.

In the opinion of the researcher no satisfactory theory of labour relations can be 
expected to come into existence until sociologists address themselves to the factors contributing to unionization, particularly the problems pointed out in the present study associated with unions that are made up exclusively of professionals.

The study of faculty unionization at Eastview demonstrates that the literature on voluntary and formal organizations is a valuable tool that can be adapted by researchers to provide important insights into the nature of professional unions. Sociologists and other members of the university community need to know more about organizations like faculty unions and the birth of many these unions over the next few years will provide unique research opportunities.

Finally, if sociologists hope to develop a satisfactory theory of labour relations, they need more information of the type derived from the present case study. In this respect it is hoped that the case study of faculty unionization at Eastview University will act as a model for further investigations which will lead to the development of a satisfactory theory of labour relations.

\section{References}

Adell, B.L. and Carter, D.D., (1972) Collective Bargaining for University Faculty in Canada. Kingston: Industrial Relations Centre, Queen's University.

Bairstow, Frances, (1968) White Collar Workers and Collective Bargaining Study prepared for the Task Force on Labour Relations. Ottawa: Queen's Printer.

Bauder, Russell, (1972) "Three Interpretations of the American Trade Union Movement," in Ray Marshall and Richard Perlman, ed., An Anthology of Labor Economics. New York: John Wiley.

Bloom, Gordon F. and Northrup, Herbert R., (1973) Economics of Labor Relations. 7 th ed. Homewood, Ill.: Richard D. Irwin.

Carnegie Commission on Higher Education, (1973) Governance of Higher Education: Six Priority Problems. New York: McGraw-Hill.

Clark, Burton R., (1960) "Cooling-out Function in Higher Education," American Jourmal of Sociology 65 (May): 569-76.

Clark, Burton R., (1966) "The Character of Colleges; Some Case Studies," in Roy J. Ingham, ed., Institutional Backgrounds of Adult Education; Dynamics of Change in the Modern University. Boston: Center for the Study of Liberal Education at Boston University.

Duryea, E.D., Risk, R.S. and associates, (1973) Faculty Unions and Collective Bargaining. San Francisco: Jossey-Bass.

Dunlop, John T., (1972) “The Development of Labor Organization: A Theoretical Framework," and "General Theory of Industrial Relations," in Ray Marshall and Richard Perlman, ed., An Anthology of Labor Economics: Readings and Commentary. New York: John Wiley.

Goldenberg, S.B., (1970) Professional Workers and Collective Bargaining. Study prepared for the Task Force on Labour Relations. Ottawa: Queen's Printer.

Gordon, C. Wayne and Nicholas Babchuk, (1966) "A Typology of Voluntary Associations," in William A. Glasser and David Sills, ed., The Government of Associations: Selections from the Behavioral Sciences. Totowa, N.J.: The Bedminster Press.

Gunderson, Morley, ed., (1975) Collective Bargaining in the Essential and Public Service Sectors. Toronto: University of Toronto Press.

Gusfield, J.B., (1966) "The Woman's Christian Temperance Union," in William A. Glasser and David Sills, ed., The Government of Associations: Selections from the Behavioral Sciences. Totowa, N.J.: The Bedminster Press.

Hameed, Syed M.A., (1975) Canadian Industrial Relations Toronto: Butterworth (Canada).

Johnson, Graham, (1975) "Voluntary Associations and Social Change," International Journal of Comparative Sociology 16 (March-June): 51-63. 


\section{A Sociological Theory of Labour Relations}

fohnston, T.L., (1970) Public Sector and White Collar Bargaining. Kingston: Industrial Relations Centre, Queen's University.

Katz, Daniel and Robert L. Kahn, (1966) The Social Psychology of Organizations. New York: Wiley. amerand, K., (1972) The Growth of White Collar Professional and Public Service Unionism and Collective Bargaining: An Annotated Anthology of Readings. Ottawa.

Marshall, F. Ray, Carlter, Allan M., and King, Allan G., (1976) Labor Economics: Wages, Employment, and Trade Unions. 3rd ed. Homewood, Ill.: Richard D. Irwin.

Maskow, M.H., (1971) "The Scope of Collective Bargaining in Higher Education," Wisconsin Law Review (1971): 33-54.

Mayo, H.B., (1969) "Universities and Government: A Preliminary Political Analysis," in Studies on the University, Society and Government. Ottawa: University of Ottawa Press.

McHugh, W.F., (1971) "Collective Bargaining with Professionals in Higher Education: Problems in Unit Determinations," Wisconsin Law Review (1971): 55-90.

Merton, Robert K., (1957) Social Theory and Social Structure. Rev. and enlarged ed. New York: The Free Press of Glencoe.

Moore, W.G., (1960) "Notes for a General Theory of Labor Organization," Industrial and Labor Relations Review 13 (April): 387-97.

Perrow, Charles, (1970) Organizational A nalysis: a Sociological View. Belmont, Calif.: Wadsworth. Proulx P.P., (1970) "Collective Negotiations in Higher Education - Canada," Paper presented to the City University of New York National Conference on the Collective Negotiations in Higher Education. Montreal: Conference of Sectors and Principals of Quebec Universities.

Queen's University. Industrial Relations Centre, (1970) Canadian Industrial Relations: Historical Background Readings. Kingston.

Queen's University. Industrial Relations Centre, (1976) The Current Industrial Relations Scene in Canada, 1976, Kingston.

Reed, G.W., (1969) White-collar Bargaining Units under the Ontario Labour Relations Act. Kingston: Industrial Relations Centre, Queen's University.

Rose, Arnold M., (1966) "Some Functions of Voluntary Associations," in William A. Glasser and David L. Sills, ed., The Government of Associations: Selections from the Behavioral Sciences. Totowa, N.J.: The Bedminster Press.

Ross, Aileen D., (1954) "Philanthropic Activity and the Business Career," Social Forces 32 (March): 274-80.

Sands, C.D., (1971) "The Role of Collective Bargaining in Higher Education," Wisconsin Law Review (1971): $151-76$

elznick, Philip, (1966) TVA and the Grass Roots; $A$ Study in the Sociology of Formal Organizations. New York: Harper and Row.

Smelser, Neil J., (1963) "Mechanisms of Change and Adjustment to Change," in B.J. Hoselitz and W.E. Moore, ed., Industrialization and Society. Paris: UNESCO.

Tice, T.N., (1972) Faculty Power: Collective Bargaining on Campus. Ann Arbor, Mich.: Institute of Continuing Legal Education.

Universities-National Bureau. Committee for Economic Research, (1962) A spects of Labor Economics: A Conference. Princeton, N.J.: Princeton University Press.

eber, Max, (1966) From Max Weber; Essays in Sociology. Edited by H.H. Gerth and C. Wright Mills. New York: Oxford University Press. 